\title{
Effect on the Dynamic Behaviour of the Form in Airport Terminal Constructions with Biomimetic Roof
}

\author{
Gonca Akcaer $^{1 *}$, Asena Soyluk ${ }^{1}$ \\ ${ }^{1}$ Department of Architecture, Faculty of Architecture, Gazi University, Eti Mah. Yükseliş sok. No 5 Maltepe-Ankara, Turkey \\ * Corresponding author, e-mail: gonca.akcaer90@gmail.com
}

Received: 05 April 2018, Accepted: 20 June 2018, Published online: 24 October 2018

\begin{abstract}
In this study, on airport terminal building design, passing long span beams and the concept of biomimesis have been the design criteria; the use of a steel structure has been examined for supporting the design form. In the airport terminal building, steel roof types in smooth surfaced, single curved-arciform, and double-curved wave forms have been designed. The three different types of steel frame roof model have been designed with the forms frequently used within the scope of the biomimesis concept and provide a covering shaped like a bird's nest, bird wing and bubble. Dynamic analysis of the three different roof forms is according to the firstdegree seismic zone and Z4 local ground class. As a result, in the long-span design criterion, the aesthetics and function influence each other and change the building's behaviour.
\end{abstract}

Keywords

airport terminal buildings, passing long span, biomimesis

\section{Introduction}

The concepts of openness and biomimesis have been determined as design criteria, and three different types of steel frame roof models designed within the concept of biomimesis have been examined to support form design. In this respect, the concepts of form and structure have been examined within the terms of this thesis and academic study. The concept of biomimesis has been experienced within a scientific discipline and in this regard, has been researched and studied.

In the article "Biomimicry as a Problem Solving Methodology in Interior Architecture", El-Zeiny (2012) discussed the concept of biomimesis. He emphasised that biomimesis is a new understanding that tries to find responses to the needs of people by imitating the organisms in nature, or by taking inspiration from their functional features and working principles of their systems. Moreover, he has argued that the primary concern of biomimesis is what the function added by form does, rather than how the organisms in nature exist.

In "Properties of Natural Organisms and Its Use in Technological Architecture", Feizabadi et al. (2012) discuss, with examples, how in current airport terminal designs, increasingly, shells in the forms described as "curved", "exuberant", "wavy" have begun to create a general culture in airport architectural typology. In addition, nature and natural formation criteria that are required by the concept of biomimesis are also explained.

In "Biomimicry in Architectural Design Education" Tavsan et al. (2015) and Zeytün's (2014) "Mimari Tasarımda Biyomorfik Yaklaşımlar" (Biomorphic Approaches in Architectural Design) postgraduate thesis, the concept of biomimesis is further explained with examples.

In another postgraduate thesis, Ataç's (2016) "Mimari biçimlenişte yorum" (Interpretation on the architectural form), the writer states that the architect must make the building decisions by determining the data and obligations affecting them, in both the creation as much as in the application. Defining the form that is the outcome of architecture action, and determining data and reasons affecting its formation is required.

In the "Structure of the New Zagreb Airport Passenger Terminal", Branko Kincl et al. (2012) explained that airport terminal buildings reflect technical and social features of the regions they are in with their structure. Accordingly, by using the leading parameters to find form, it has been concluded that it needs to be resolved with a technical and flexible structure providing contemporary interaction through artistic creativity. 
In the study "Material, Form and Force", Toni Kotnik and Michael Weinstock (2011) conclude that integrating material, form and force effects in the design process reveals new practical findings within the scope of finding form.

Olga Popovic Larsen's (2008) "Reciprocal Frame Architecture" book features the frame element discussed within the scope of structural and architectural concepts; design and construction are explained with diagrams and models.

In Serkan Y1lmaz's (1999) thesis, "Evolution of the Architectural Form Based on the Geometrical Concepts", it emerges that the basic geometrical forms used to create architectural form are used by taking the place organisation into consideration.

\section{Biomimesis Airport Terminal Building Examples}

As a result of the research, the use of basic geometric forms, which are used to create forms, takes place given space organisation. The upper shell approach in the forms described as "curved" and "wavy", covering wide openings in their designs, have started to set an example in airport architecture typology. Within the scope of the research, three airport examples were examined:

1. J. F. Kennedy International Airport, New York: The upper layer of Eero Saarinen's JFK Airport evokes the action and concepts of flying and has become the symbol of New York city as "as an eagle to land". The designer's own words relating to design intentions of this construction stated that "It is a structure that has an architecture expressing drama, freedom and the excitement of travel; a place of departure and passage. Figures have been chosen intentionally in order to emphasize the characteristics of flying by rising of the line" (Fig. 1).

2. Shenzen Bao'an Airport, China: The wall less and roofless design of the construction brings out an

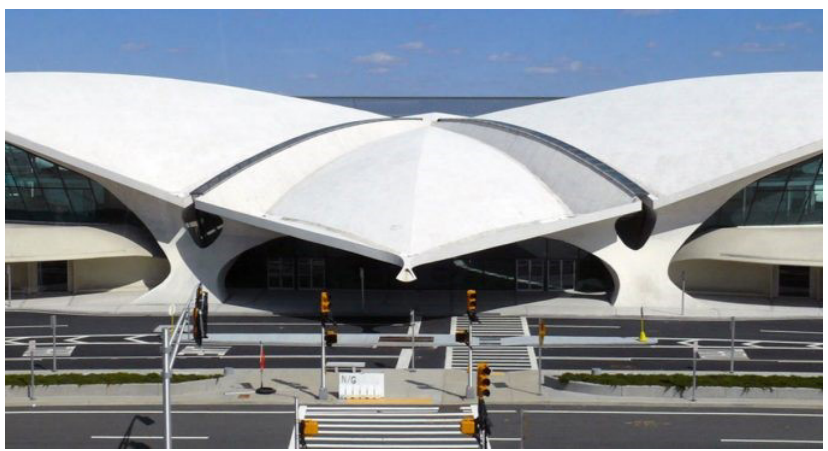

Fig. 1 TWA Terminal, J. F. Kennedy International Airport Perspective View, New York (WikiArquitectura, 2017). organic sculptural form. The upper roof of the airport has two separate layers, internal and external, with structural elements between them. This spacious structure, rejecting the concept of the classical structure, surrounds the passengers during their journey in the terminal. At the same time, based on the design concept, there are also "honeycomb" panels composing the basic physical elements of the shell (Fig. 2) (Website-2, 2017).

3. Peking Airport, China: The construction has southeast directed skylights to most effectively benefit from the morning sun. Departures and arrivals are on the same floor. With its elliptical shape and glass titanium mixed dome, it is likened to a huge egg (Fig. 3).

\section{Field Work}

Architects make decisions in the form design stage that constitute one of the most important points of the design stage. When deciding on the format, form research is carried out, and modern building technology and building materials are examined. In the conducted study, an A-class airport terminal building has been designed.

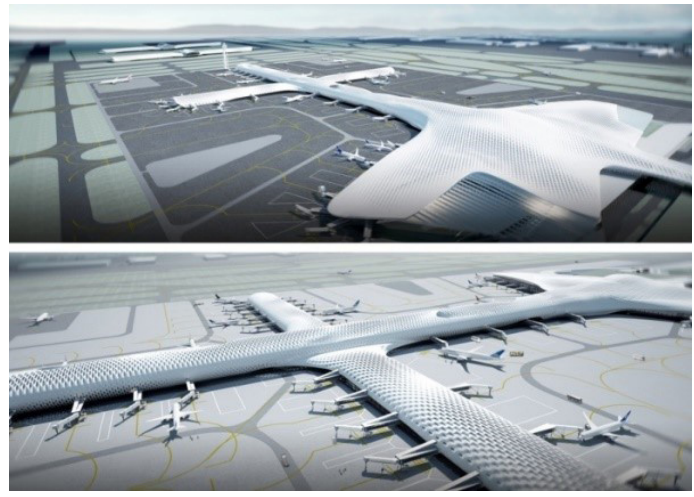

Fig. 2 Shenzhen Bao'an Airport-China, Guangdong-Roof Construction View (archdaily, 2017).

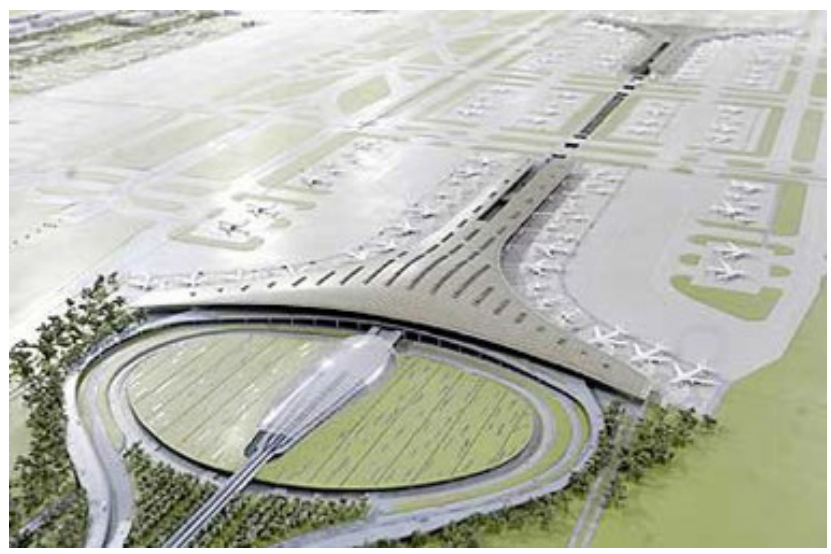

Fig. 3 Peking Airport Perspective View (Foster + Partners, 2017). 
The terminal building designed has been constituted integrally in rectangular form and without dilation. The system consists of two basements, one ground floor and first floor. To allow the construction to have a light, flexible design, and see better the setpoints (period, displacement, and base shear values), using statistical analysis a steel carrier system has been chosen. Axis ranges of the system are $45 \mathrm{~m}$ at the basements, ground floor and top floor. Floor heights are kept fixed at each floor at $9 \mathrm{~m}$. It is a construction with a $45 \mathrm{~m} \times 90 \mathrm{~m}$ seating area, $18.15 \mathrm{~m}$ high, with two x-direction spans and one y-direction span, with a steel frame beamed roof system at the top. The construction has been designed with a linear structure regarding space requirements. In this direction, each side has a main passenger axis centralised with the ability to expand. On the air side of the axis, there are smooth, geometrical finger-like air bridges. Flooring in the construction is made of in-situ concrete on steel decks. In-situ concrete flooring designed to work together with the steel beams show rigid diaphragm behaviour. To increase the robustness of the floor diaphragm, horizontal crossings were arranged on the flooring plane. The frontage was covered with cladding elements. Trusses and purlins were placed in the short direction in the project. The material specification being steel frame profiles St 52(S355JR) steel. Beam sizes are $80 \mathrm{~cm}$ diameter tubular sections in the ground floor and $60 \mathrm{~cm}$ diameter on the first floor. Truss ranges are every $3 \mathrm{~m}, 3 \mathrm{~m}$ height. Purlins are every $1.5 \mathrm{~m}$, and span $3 \mathrm{~m}$ on the ground floor; on the first floor every 3 $\mathrm{m}$ and spanning $3 \mathrm{~m}$ span, and are $3 \mathrm{~m}$ in height. Dynamic analysis of the three different roof-form designs has been carried out in the first-degree seismic zone and Z4 local ground class. Seismic analysis is the first stage of earthquake risk analysis, which has an important place in projecting large-scale engineering structures. Mode values, the maximum displacement value and the determination of base shear values constitute the subject of seismic analysis. The seismic analysis aims to calculate the parameters related to the required earthquake ground motion in calculating any likely earthquake loading conditions of the ground and engineering structure. Therefore, regarding structure typology, in a building with a high density such as an airport, to examine wide roof openings and different roof types from aesthetic and visual points of view in terms of different ground and earthquake grades, this will provide preliminary preparation. (Fig. 4 and Fig. 5).

The form was selected with a smooth frame beam system to support the bird's nest form with the structure; with

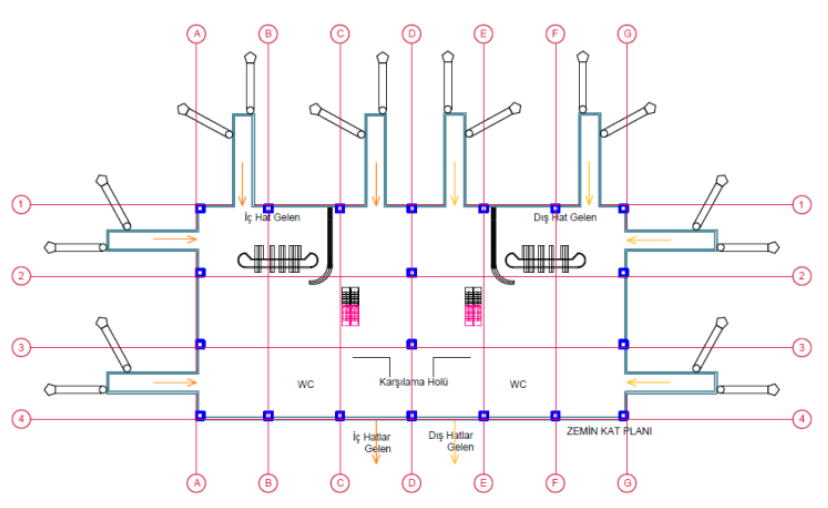

Fig. 4 Designed Airport Terminal Building Ground Floor Plans

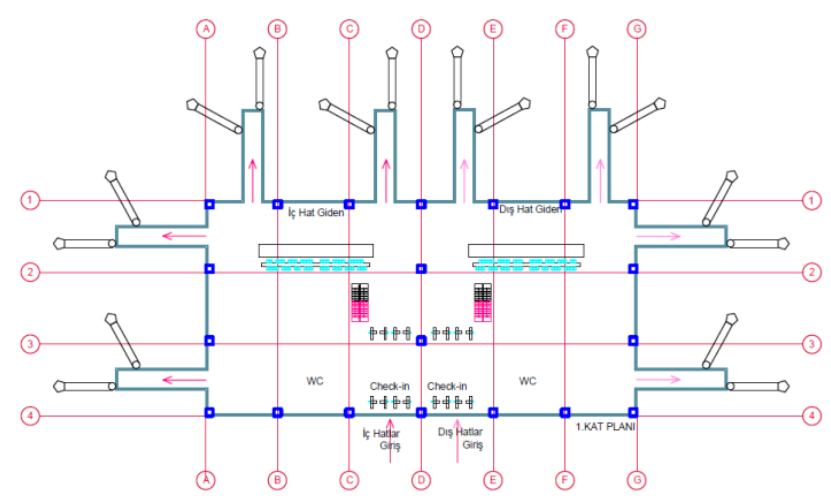

Fig. 5 Designed Airport Terminal Building First Floor Plans

an arciform frame beam system to support the bubble form with the structure, and with a specially designed wavy frame beam system to support the bird wing form structure. Moreover, the structure-form compatibility has been provided with the coating material in top view. The designed airport terminal building carrier system was modelled in the $1^{\text {st }}$-degree seismic zone and local ground class Z4 effect, and in the Sap 2000 V18 program. When calculating the loads, the construction will be exposed to, it generally benefited from the TS498, DBYYHY 2007, TS648, AISC-ASD 89 and IBC 2009 (Deflection Classes) and regulations and standards. For Z4, spectrum characteristic periods are taken as TA:0.20, TB:0.90 (Table 1).

Section Sizes: All elements have been designed as the frame element. Each type has 56851 elements in total.

Table 1 Spectrum Characteristic Periods (TA, TB) (Ataç, 2006)

\begin{tabular}{lcc}
\hline Local Ground & TA & TB \\
\hline Z1 & 0.10 & 0.30 \\
Z2 & 0.15 & 0.40 \\
Z3 & 0.15 & 0.60 \\
Z4 & 0.20 & 0.90 \\
\hline
\end{tabular}


Structural sizes are $45 \mathrm{~m} \times 90 \mathrm{~m}$. The columns have been designed to provide one every $15 \mathrm{~m}$ at the edges of the structure, and two columns every $45 \mathrm{~m}$ at the central point. Steel columns, beams, purlins and trusses have diameters and wall thicknesses according to Table 2.

Material Information: For the airport terminal building modelled with the response spectrum method, tubular section columns and trusses, and I profile purlins and beams were used. Floorings have been designed as a concrete floor on the trapeze. In floors, crosses were placed, and it works as a rigid diaphragm. In the design of the system, St52 (S355JR) structural steel has been used; its required features are given in Table 3.

Load Combinations: Fixed loads, own loads, snow loads, horizontal and vertical earthquake loads that influence the construction system have been taken in accordance with the AISD 89 (McKenzie et al., 2005). Loads considered in the calculation: Coating loads have been transferred over the purlin element as uniformly distributed loads (Table 4).

Table 2 Diameters and Wall Thicknesses of the Columns, Beams,

\begin{tabular}{lcc}
\multicolumn{3}{c}{ Purlins and Trusses } \\
\hline Column (Tubular Section) & Diameter & Wall Thickness \\
\hline Ground Floor & $80 \mathrm{~cm}$ & $16 \mathrm{~cm}$ \\
$1^{\text {st }}$ Floor & $60 \mathrm{~cm}$ & $10 \mathrm{~cm}$ \\
Beam (I Profile) & \\
Ground Floor & $100 \mathrm{~cm}$ & $20 \mathrm{~cm}$ \\
$1^{\text {st }}$ Floor & $50 \mathrm{~cm}$ & $12 \mathrm{~cm}$ \\
Purlin (Tubular Section) & & $10 \mathrm{~cm}$ \\
Ground Floor & $50 \mathrm{~cm}$ & $8 \mathrm{~cm}$ \\
$1^{\text {st }}$ Floor & $30 \mathrm{~cm}$ & \\
Truss (Tubular Section) & & $8 \mathrm{~cm}$ \\
Ground Floor & $30 \mathrm{~cm}$ \\
$1^{\text {st }}$ Floor & $20 \mathrm{~cm}$ & $6 \mathrm{~cm}$ \\
\hline
\end{tabular}

Table 3 Properties of the material used in the steel system for the airport terminal building modelled with the response spectrum method

\begin{tabular}{lc}
\hline Element & St52-S355JR \\
\hline Type of Element & Frame \\
Modulus of Elasticity $(\mathrm{GPa})$ & 210.00 \\
Tensile Strength $(\mathrm{GPa})$ & 510.00 \\
Yield Point $(\mathrm{GPa})$ & 355.0 \\
Shear Modulus $(\mathrm{GPa})$ & 80.769 \\
Poisson's Ratio & 0.30 \\
Heat Expansion Coefficient & $1.17 \times 10$ \\
Unit Weight $\left(\mathrm{KN} / \mathrm{m}^{3}\right)$ & 76.97 \\
\hline
\end{tabular}

Table 4 Loads Considered in Calculation

\begin{tabular}{|c|c|}
\hline Ground Floor: & $1^{\text {st }}$ Floor: \\
\hline $\begin{array}{l}\text { 1. Dead Loads: } \\
\text { a. Own Load: } 7850 \mathrm{~kg} / \mathrm{m}^{3}(\mathrm{SW}) \text {, } \\
\text { b. Trapeze: } 10 \mathrm{~kg} / \mathrm{m}^{2}(\mathrm{DL}), \\
\text { c. Concrete: } 375 \mathrm{~kg} / \mathrm{m}^{2}=15 \mathrm{~cm} \times \\
2500 \mathrm{~kg} / \mathrm{m}^{3}(\mathrm{DL}) \text {, } \\
\text { d. Leveling Screed: } 72 \mathrm{~kg} / \mathrm{m}^{2}= \\
3 \mathrm{~cm} \times 2400 \mathrm{~kg} / \mathrm{m}^{3}(\mathrm{DL}), \\
\text { e. Marble: } 81 \mathrm{~kg} / \mathrm{m}^{2}=3 \mathrm{~cm} \times 2700 \\
\mathrm{~kg} / \mathrm{m}^{3}(\mathrm{DL}), \\
\text { f. Installation: } 50 \mathrm{~kg} / \mathrm{m}^{2}(\mathrm{DL}) \\
\text { Total: own }+578 \mathrm{~kg} / \mathrm{m}^{2} \sim 600 \mathrm{~kg} / \mathrm{m}^{2} \\
\text { 2. Moving Load: } 500 \mathrm{~kg} / \mathrm{m}^{2}(\mathrm{LL})\end{array}$ & $\begin{array}{l}\text { 1. Dead Loads: } \\
\text { a. Own: } 7850 \mathrm{~kg} / \mathrm{m}^{3} \\
\text { For aluminium; } \\
\text { b. Top Coat: } 25 \mathrm{~kg} / \mathrm{m}^{2} \\
\text { (Aluminium) } \\
\text { c. Bottom Coat: } 25 \mathrm{~kg} / \mathrm{m}^{2} \\
\text { (Aluminium) } \\
\text { d. Installation: } 30 \mathrm{~kg} / \mathrm{m}^{2} \\
\text { Total: own + } 80 \mathrm{~kg} / \mathrm{m}^{2} \\
\text { (Aluminium) } \\
\text { 2. Service Load: } 100 \mathrm{~kg} / \mathrm{m}^{2}(\mathrm{Lr}) \\
\text { 3. Snow Load: } 75 \mathrm{~kg} / \mathrm{m}^{2}(\mathrm{~S})\end{array}$ \\
\hline \multicolumn{2}{|l|}{$\begin{array}{l}\text { Frontage: } \\
\text { a. Dead Loads: Own: } 7850 \mathrm{~kg} / \mathrm{m}^{3} \\
\text { b. Coating: } 15+25=40 \mathrm{~kg} / \mathrm{m}^{2} \\
\text { c. Total: own }+40 \mathrm{~kg} / \mathrm{m}^{2}\end{array}$} \\
\hline
\end{tabular}

Fixed Loads: Fixed loads have been described as static loads occurring due to the own weight of all the elements constituting the system in TS 498 and TS648 regulations. In this system, the self-weight of the elements constituting the carrier system and the roof coating have been considered as the fixed loads. Spectrum Coefficient: Spectrum coefficient is a value depending on the local ground conditions and building natural period. As seen in Table 5, the Z4 local ground class has been discussed.

Static and dynamic calculation of the construction was modelled three-dimensionally with the sap 2000 computer program by using the spectrum diagrams given in Fig. 6 .

Views modelled in the sap 2000 program of the airport terminal buildings that have three different roof type designs can be seen in Table 6 .

Table 5 Spectrum Characteristic Periods (TA, TB)

\begin{tabular}{lcc}
\hline Local Ground & TA & TB \\
\hline Z4 & $0.20 \mathrm{sec}$ & $0.90 \mathrm{sec}$ \\
\hline
\end{tabular}

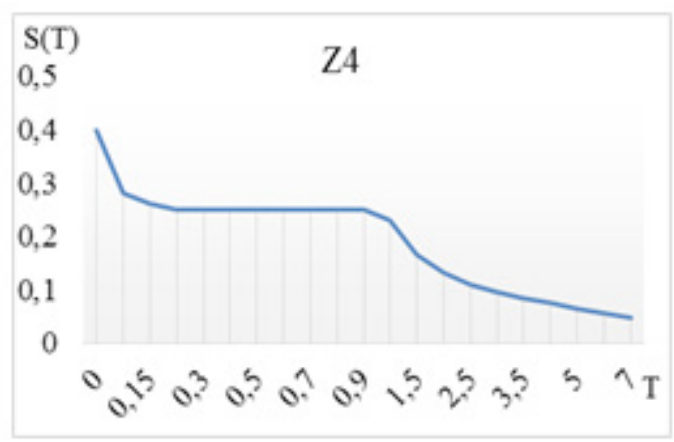

Fig. 6 Spectrum Curve for the Z4 ground class. 
Table 6 Spectrum Characteristic Periods (TA, TB)

Roof system of Type 1 has been designed inspired by a bird's nest
and resolved with the smooth-surfaced steel frame system.

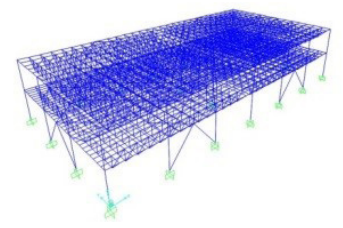

Type 2 model has been designed inspired by the bubble form and resolved with the arciform single curved frame roof system.

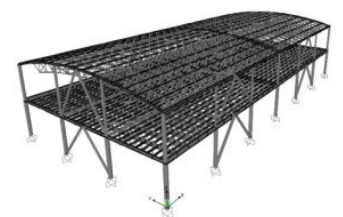

Type 3 model has been designed inspired by the bird wing form and resolved with the frame roof system constituted in a special form.

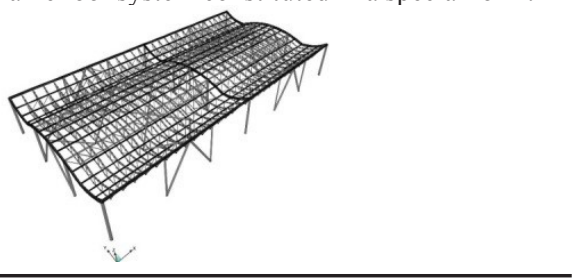

\section{Comparison of the Findings Related to Type 1, 2 and}

\section{Construction Model}

As seen in Fig. 7 and Tables 7, 8 and 9, the Mode 1 value of arciform Type 3 was $5.99 \%$ lower compared to the Mode 1 value of Type 1 , and $11.51 \%$ higher compared to the Mode 1 value of Type 3. The Mode 2 value of Type 2 was $7.69 \%$ lower compared to the Mode 2 value of Type 1 , and $10.88 \%$ higher compared to the Mode 2 value of Type 3. The Mode 3 value of Type 2 was $4.00 \%$ lower compared

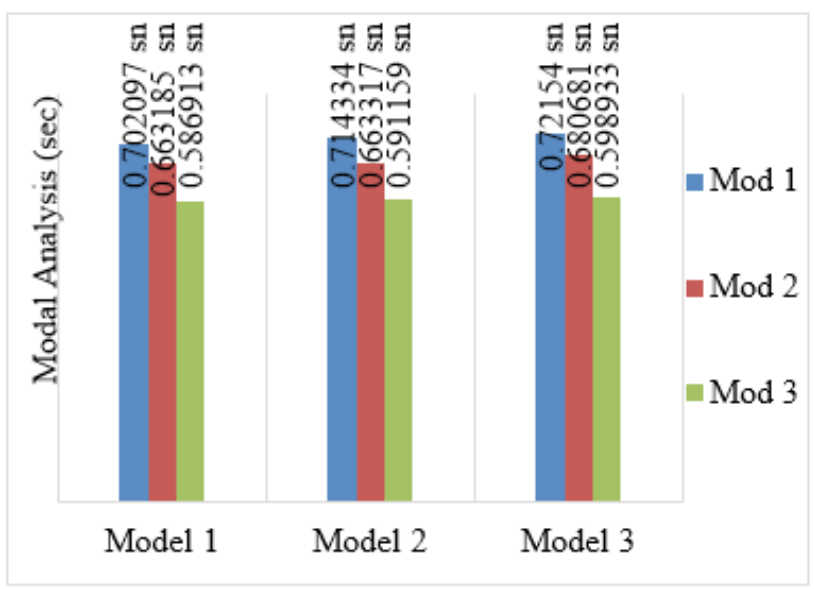

Fig. 7 Comparison of the First 3 Mode Values for Type 1, Type 2 and Type 3 (sec)
Table 7 Modal Analysis, Mod 1 (Model 1, 2 and 3)

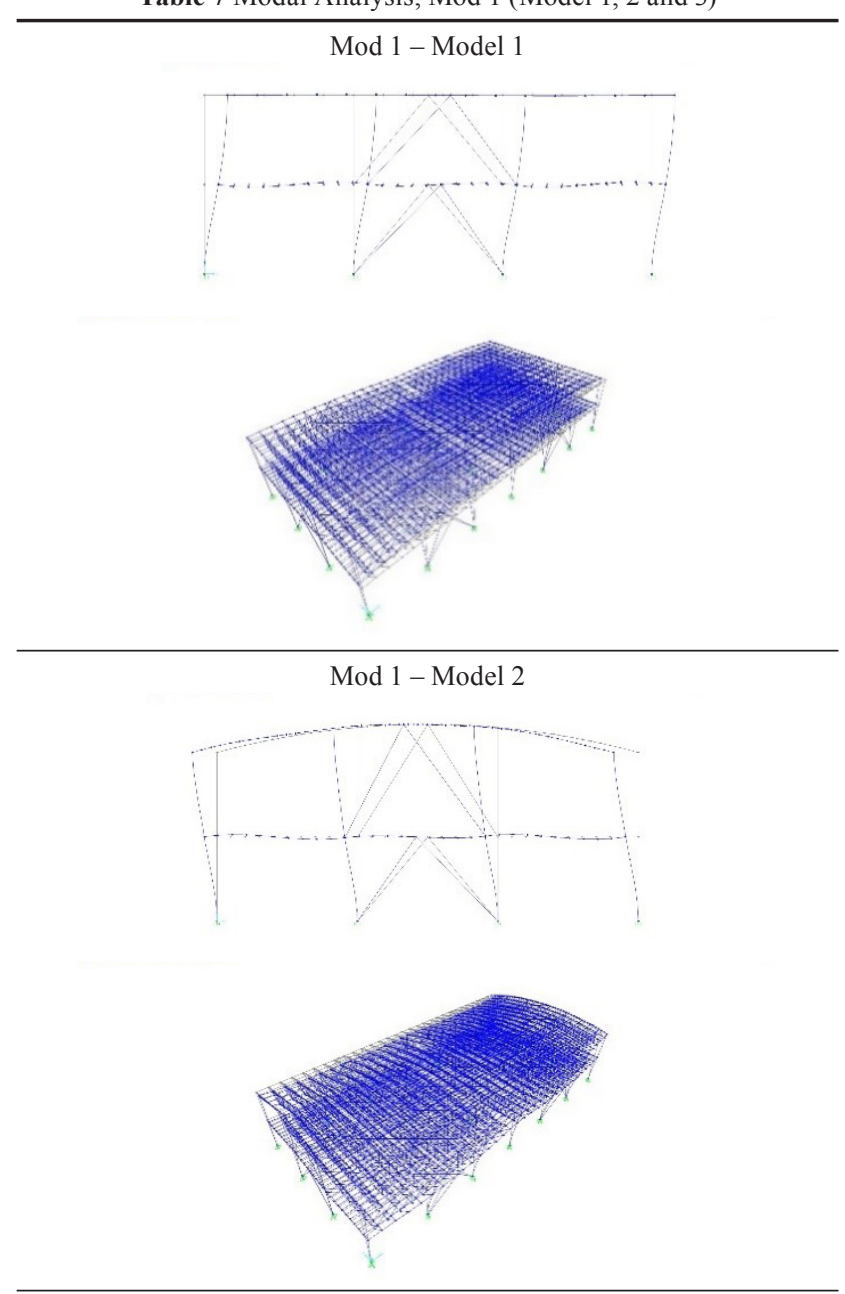

Mod 1 - Model 3
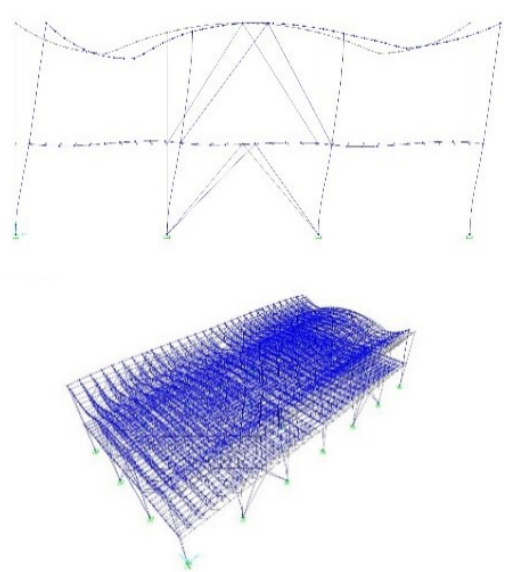

to the Mode 3 value of Type 1, and $12.01 \%$ higher compared to the Mode 3 value of Type 3 .

As seen in Fig. 8, in the Type 3 model, column, truss and purlin section values have increased due to the wave form of the roof truss. Due to this increase, the construction weight has also increased. Since the total construction 

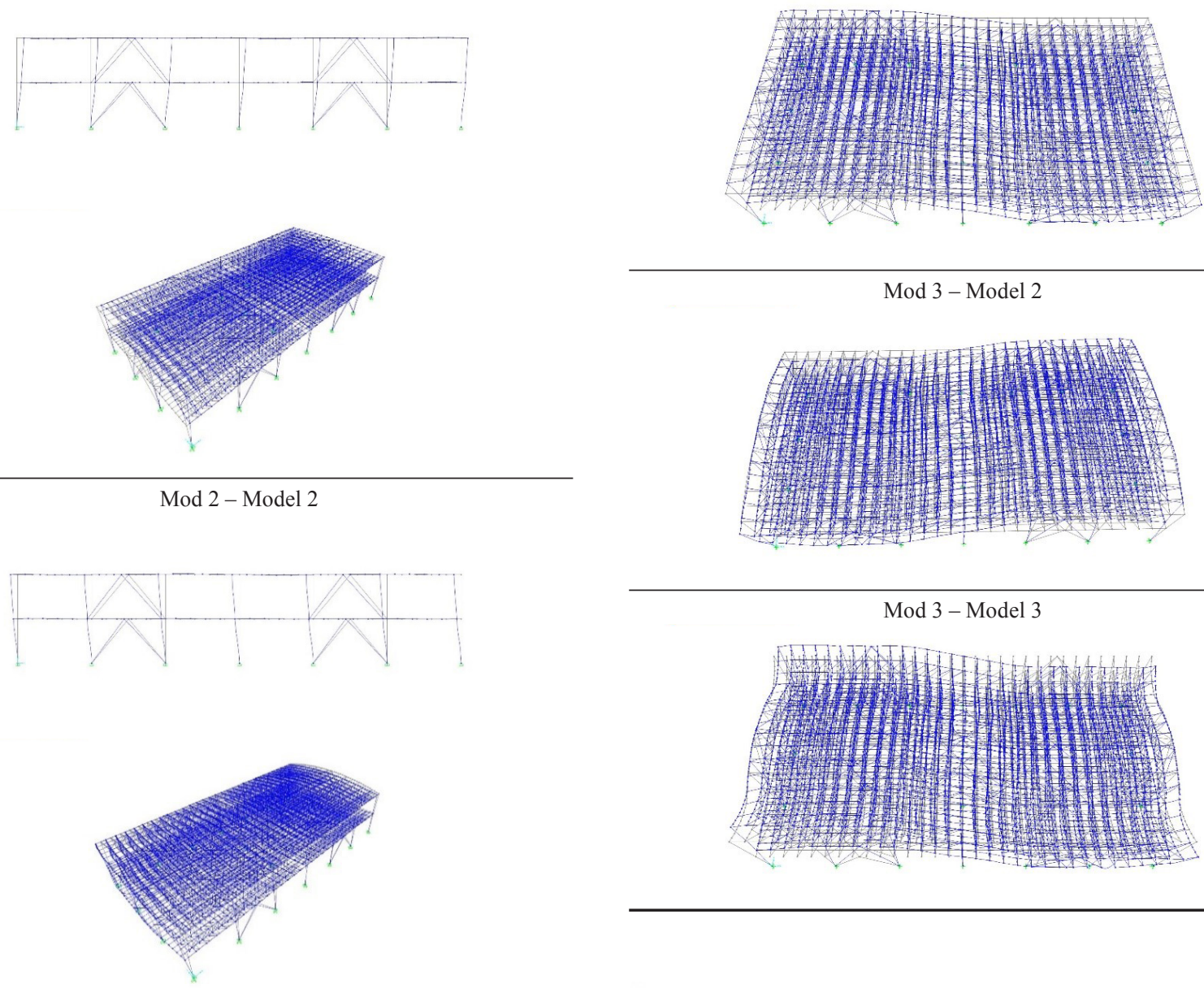

Mod 2 - Model 3
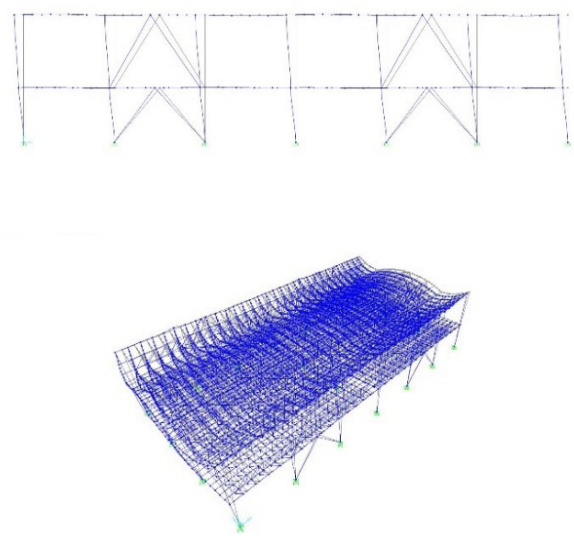

weight of the arciform Type 2 is $0.93 \%$ higher compared to Type 1, and $5.19 \%$ lighter than Type 3, the arciform type has been selected.

As seen in Fig. 9, the maximum base shear value of the arciform Type 2 in the $\mathrm{x}$-direction was $1.23 \%$ lower than

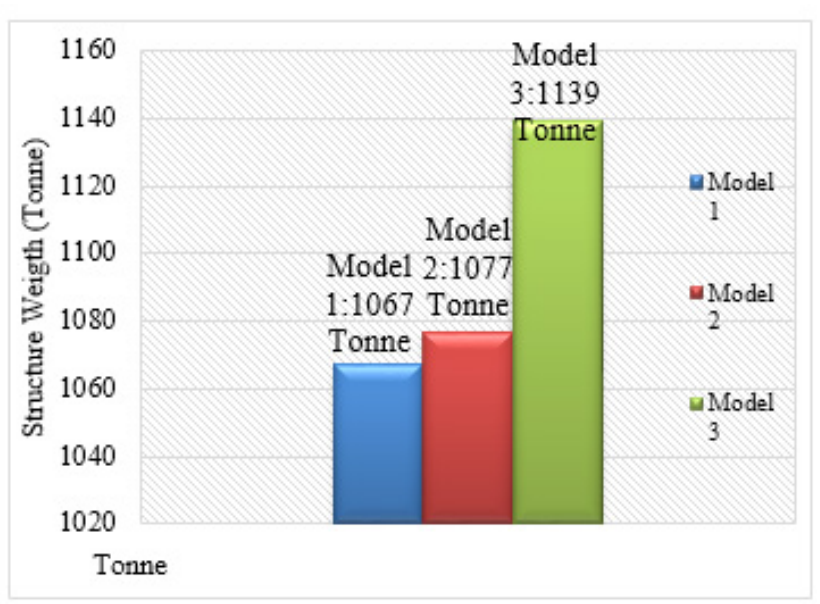

Fig. 8 Construction Weight Values of Three Different Steel Frame Roof Designs (Tonne)

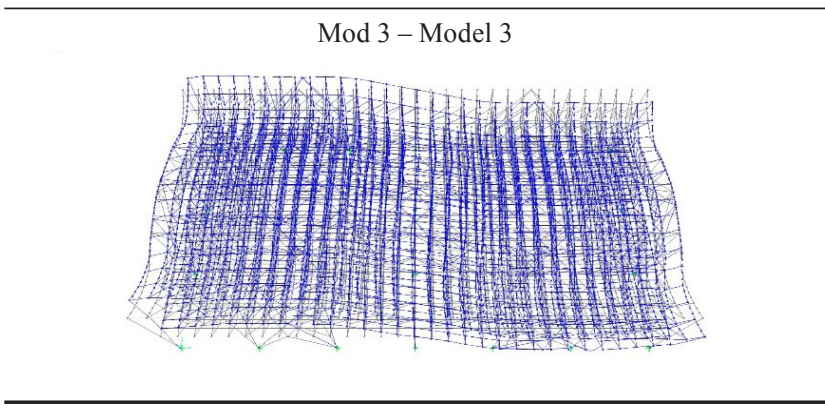

Type 1, and $3.39 \%$ higher than Type 3 . The maximum base shear value of Type 2 in the y-direction was $2.68 \%$ lower compared to Type 1 and $0.71 \%$ lower compared to Type 3 . Because the maximum base shear value of Type 2 was lower compared to Type 1 and Type 3 , arciform has been selected. 


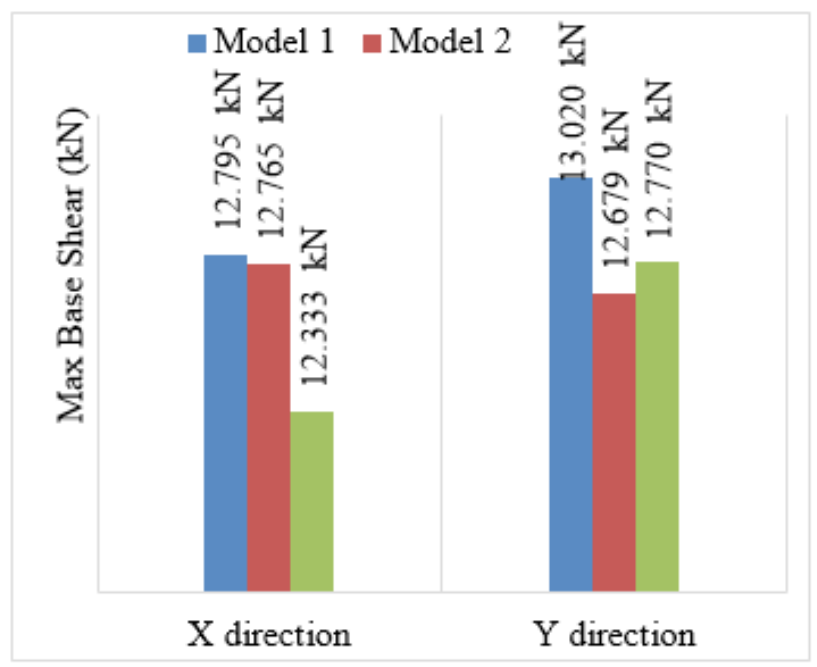

Fig. 9 For Type 1, Type 2 and Type 3 Comparison of the Maximum Base Shear Values in X and Y Directions in DZ14 (KN)

Maximum displacement values are at the $2758^{\text {th }}$ nodal point in the $\mathrm{x}$-direction, and $16^{\text {th }}$ nodal point in the $y$-direction. As seen in Fig. 10, the maximum displacement value of the arciform Type 2 in the $\mathrm{x}$-direction is the $2758^{\text {th }}$ nodal point of the selected nodal points; and it was $7.59 \%$ higher than Type 1, $28.08 \%$ lower than Type 3. The maximum displacement value of the arciform Type 2 in the y-direction is the $16^{\text {th }}$ nodal point of the selected nodal points; and since it was $13.37 \%$ higher than Type 1 and $18.86 \%$ lower than Type 3, the arciform has been selected.

As a result of the analysis, the form of the airport terminal building has been decided. When comparing the modal analysis, maximum base shear and displacement values in the $1^{\text {st }}$ degree seismic zone and $\mathrm{Z} 4$ ground class, and the response spectrum analysis with the construction weight; the maximum base shear value of the arciform in

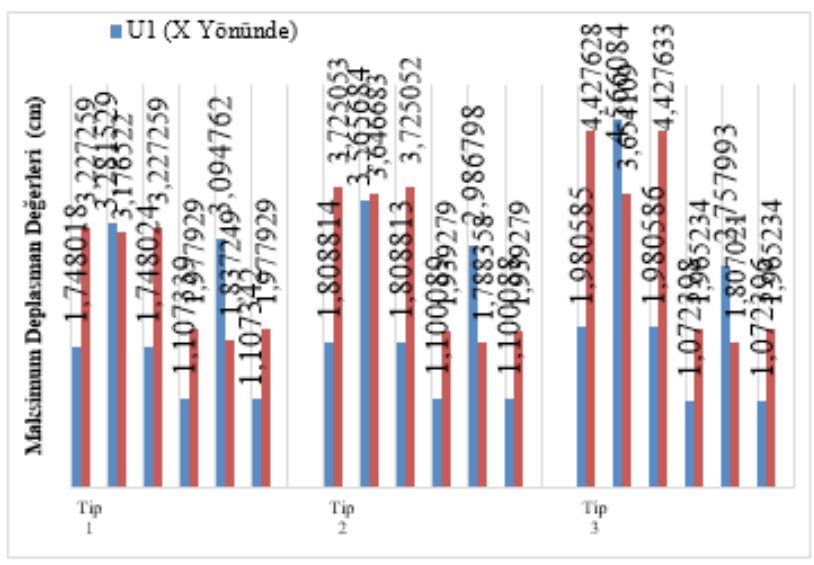

Fig. 10 For Type 1 Type 2 and Type 3 Comparison of the Maximum Displacement Values in DZ14 (cm) x-direction was $0.23 \%$ lower than the smooth surfaced form, and $3.39 \%$ higher than the wave form. The maximum base shear value of the arciform in the y-direction was $2.68 \%$ lower than the smooth surfaced form, and $0.71 \%$ lower than the wave form.

The maximum displacement value of the arciform in the $\mathrm{x}$-direction is at the $2758^{\text {th }}$ nodal point of the selected nodal points and was $7.59 \%$ higher than the smooth surfaced form and $28.08 \%$ lower than the wave form. The maximum displacement value of the arciform in the $y$-direction is the $16^{\text {th }}$ nodal point of the selected nodal points, and since it was $13.37 \%$ higher than the smooth surfaced form and $18.86 \%$ lower than the wave form, the arciform has been selected.

The Mode 1 value of arciform was $5.99 \%$ lower compared to the Mode 1 value of the smooth surfaced form, and $11.51 \%$ higher compared to the Mode 1 value of the wave form. The Mode 2 value of the arciform was $7.69 \%$ lower than the Mode 2 value of the smooth surfaced form, and $10.88 \%$ higher than the Mode 2 value of the wave form. The Mode 3 value of the arciform was $4.00 \%$ lower than the Mode 3 value of the smooth surfaced form, and $12.01 \%$ higher than the Mode 3 value of the wave form.

In the wave form model, the column, truss and purlin section values have increased due to the wave form of the roof truss. Due to this increase, the construction weight has also increased. Total construction weight of the arciform was $0.93 \%$ higher compared to the smooth surfaced form, and $5.19 \%$ lighter compared to the wave form.

\section{Conclusion}

Due to airport terminal buildings being places where the functional actions are frequent and active, they are a type of building that require long spanned coverings. Integrity and easy detection of the place is important. The material that allows the constructions to be functionally more flexible and useful by providing these long spans with a column-free and light structure is steel. Biomimesis, which is a concept used today, is a new understanding that tries to find responses to the needs of people by imitating the organisms in nature, or by taking inspiration from their functional features and working principles of their systems. It can be seen that there is an effort to produce lighter and more resistant constructions with the materials and techniques developed with the principles of Biomimesis.

Using place requirements within the scope of the work, an A-class, 45-meter span passing in rectangular form with a linear concept airport terminal building has been designed. To span 45 meters and design column-free 
places, a steel carrier system has been selected. In the context required by the biomimesis concept, in the airport terminal construction, bubble forms, bird's nest and bird wing approaches have been selected for the roof formats and coating material. To reflect these forms aesthetically, visually and to support the structure of the form, the bird's nest has been designed with the smooth-surfaced frame system, bubble has been designed with the arciform single-curved frame system, and the bird wing has been designed with the wavy double curved frame system. As a consequence of the analysis, the form for the airport terminal building has been selected. Comparing the modal analysis, maximum base shear and displacement values in the $1^{\text {st }}$-degree seismic zone and $\mathrm{Z} 4$ ground class response spectrum analysis with the construction weight, the arciform has been selected. However, biomimesis, which is also one of the architectural design criteria, is based on the principle of providing the highest resistance with the least material. At this point, because the wave form makes the construction heavier, it contradicts this principle. The arciform that was selected as a consequence of the analysis has been one of the construction forms used for long spans from past to present, and they are the constructions supported by the horizontal reactions as well as the vertical reactions.

The main goal of modern design is the rational use of mechanical systems and structure. Airport terminal buildings that have a modern carrier system are iconic

\section{References}

Ataç, B. (2006) "Mimari biçimlenişte yorum" (Interpretation on the architectural form), MSc Thesis, Trakya University. (in Turkish)

El-Zeiny, R. M. A. (2012) "Biomimicry as a Problem-Solving Methodology in Interior Architecture", Procedia - Social and Behavioral Sciences, 50, pp. 502-512.

https://doi.org/10.1016/j.sbspro.2012.08.054

Feizabadi, M., Bemanian, M. R., Golabchi, M., Ansari, M., Mirhosseini, S. M. (2012) "Properties of natural organisms and its use in technological architecture", International Journal of Architectural Engineering \& Urban Planning, 22(2), pp. 65-71.

Kincl, B., Neidhardt, V., Radić, J., Vlašić, A., Mujkanović, N. (2012) "Structure of the New Zagreb Airport Passenger Terminal", Gradevinar, 64(6), pp. 475-484.

Kotnik, T., Weinstock, M. (2012) "Material, Form and Force", Architectural Design, 82(2), pp. 104-111. https://doi.org/10.1002/ad.1386

McKenzie, D. L., Kaehler, R. C., Landwehr, K. (2005) "An American National Standard-AISC-ASD 89-Specification for Structural Steel Buildings", American Institute of Steel Construction, Inc., Chicago, USA.

Popovic Larsen, O. (2008) "Reciprocal Frame Architecture", 1st ed., Elsevier Architectural Press, Oxford, UK. constructions both for today and the future and result from the opportunities brought by structure, form setup and place aesthetics. It has been shown that the criteria in format and form selection at the architectural stage are closely associated with the structural behaviour of the construction. Moreover, the behaviour of these kinds of construction under the horizontal load has changed with form and the mass weight, emphasising that the architects of these constructions also undertake an important role in any potential damage that may occur. As a result of the analysis, the proven arciform has given optimum results for constructions that need to be light to pass the long spans with the least material and being the lower of the displacement values compared to the other forms. It benefits from the arciform in concepts such as biomimesis, with its long spans from past to present. Designing constructions requiring long span resolution, due to the functional requirement, with the steel frame carrier systems, has been one of the important matters driving architecture and engineering. This is especially the case in the examined frame beamed systems; the arches, which give optimum results in the conducted analyses, also serve the construction aesthetically.

\section{Acknowledgement}

The project presented in this article is supported by Civil Engineer Emre Sakabaş who helped for the use and analysis of the A Probina and Sap2000 programs.

Tavsan, C., Tavsan, F., Sonmez, E. (2015) "Biomimicry in Architectural Design Education", Procedia - Social and Behavioral Sciences, 182, pp. 489-496. https://doi.org/10.1016/j.sbspro.2015.04.832

WikiArquitectura "TWA Terminal, J. F. Kennedy International Airport, New York", [online] Available at: https:/en.wikiarquitectura.com/ building/twa-terminal-at-jfk-airport/ [Accessed: 10 August 2017]

archdaily "Shenzhen Bao'an International Airport / Studio Fuksas", [online] Available at: http:/www.archdaily.com/472197/ shenzhen-bao-an-international-airport-studio-fuksas [Accessed: 10 August 2017]

Foster + Partners "Beijing Capital International Airport", [online] Available at: https://www.fosterandpartners.com/projects/beijingcapital-international-airport/ [Accessed: 10 August 2017]

Yilmaz, S. (1999) "Evolution of the Architectural Form Based on the Geometrical Concepts", MSc Thesis, Izmir Institute of Technology University Science Institute.

Zeytün, B. (2014) "Mimari Tasarımda Biyomorfik Yaklaşımlar" (Biomorphic Approaches in Architectural Design), MSc Thesis, Yakındoğu University. (in Turkish) 